\title{
Adolescent Lifestyles in Malaysia
}

\section{Fariza Md Sham}

Faculty of Islamic Studies \& Institute of Islam Hadhari, The National University of Malaysia; farisham@ukm.edu.my

Siti Zaleha Shafi'e

Faculty of Islamic Studies, The National University of Malaysia (UKM); zalehashafie90@gmail.com

\section{Syaidatun Nazirah Abu Zahrin}

Institute of Islam Hadhari, The National University of Malaysia; syaidatun77@hotmail.com

\section{Doi:10.5901/mjss.2015.v6n6s1p271}

\section{Abstract}

The influence of globalization has also made its impact on adolescent lifestyle. This is due to adolescent exposure to various international society lifestyles which differ in values from local socio-cultural and Islamic values. Lifestyles which contradict with Islamic teachings are not permissible in the context of the Muslim society in Malaysia.Thus, this research is conducted to examine the forms of adolescent lifestyle in Malaysia. The purpose is to identify the forms of lifestyle practised by adolescents inBandar BaruPermas Jaya, Johor Bahru, Malaysia. For this purpose, the researcher has conducted a field study on 510school adolescents of Permas Jaya National Secondary School. Questionnares used consists of 15 questions covering three forms of lifestyle, i.e., consumptive, modern and hedonistic.Research findings are analysed using descriptive statistical technique explained in the form offrequency(f), percentage (\%) and mean.Findings show that adolescents in Bandar BaruPermas Jaya, Johor Bahru, Malaysia practise three forms of lifestyle. However, on comparison, the modern lifestyle is on the whole practised by the majority of adolescents in Malaysia.

Keywords: Lifestyle, Adolescent, Consumptive, Modern, Hedonistic

\section{Introducton}

Lifestyle is a characteristic of individual behavior that related to social relations, consumption, entertainment and way of dressing that become habitual and logical action.A practised lifestyleis an identity of individual attitudes, values and views. Thus, lifestyle is a way to nurture self-concept and identifies culture highlighted in a personal identity.

Lifestyle is a characteristic of individual behaviour that related to social relations, consumption, entertainment and way of dressing that become habitual and logical action. A practised lifestyle is an identity of individual attitudes, values and views. Thus, lifestyle is a way to nurture self-concept and identifies culture highlighted in a personal identity.

In principle, lifestyle is an identity of a person's daily life pattern. There are various concepts which may explain lifestyle. According to Mowen, "Life style relates to how people live, how they spend their money, and how they allocate their time" (Mowen,1995). Based on this definition, lifestyle is about how one life, spends money, and manages time, what one feels as important within one's interest circle, what one feels about oneself and the surrounding world (Mowen, 1995). Engel defines lifestyle as a life pattern related to how time and money are spent. He also says that a person's lifestyle is influenced by experience, social class, demography and etc (Engel, 1990).

In the context of an Islamic lifestyle, al-Quran in principle states in surah al-Baqarah 2:82 as a guide to mankind that an Islamic lifestyle is implementing what is commanded and leaving what is prohibited by Allah s.w.t. and His Prophet (pbuh), which are categorised as aqidah, ibadah and akhlaq. SayyidQutb said that inner faith or belief appears from the heart in the form of righteous deeds (Qutb,1967). Faith does not exist until righteous deeds appear from the heart, i.e. a strong aqidah, proper implementation of ibadah and practice of Islamic akhlaq. Further, Wahbah al-Zuhayli (1989), interprets the above verse as, whoever believes in Allah s.w.t., His Prophet (pbuh), day of Resurrection, does righteous deeds as well as fulfills obligations and avoids the forbidden, will go to paradise (Wahbah al-Zuhayli,1989). It is thus clear that the strength of faith which appears in an individual's heart is indicated through his behaviour, i.e., in the practice of Islamic values based on aqidah, ibadah and akhlaq. Therefore, the bond that ties these three elements cannot 
be separated in practice in a Muslim's daily life or what is referred to as an Islamic lifestyle.

Therefore, lifestyle is a frame of reference used by adolescents in their behaviour. Adolescents strive to make all aspects of his life connected within a certain form, and strategise how it they wish it to be perceived by others. Adolescent lifestyle is a comprehensive term which covers their fashion, entertainment, how they spend their leisure, choice of food, place of residence, use of gadgets and tools, accessories and etc. The form of lifestyle they practice influences their behaviour.

A theory about lifestyle by Assael states that lifestyle is the life pattern of a person which results from his activities, interests and opinions (Assael,1992). This theory is supported by Joseph T. Plummer and Ibrahim Abu Shah et al. who divide lifestyle into segments as follows: (Plummer,1974), Ibrahim Abu Shah et al.,1999).

Table 1: Lifestyle according to Activities, Interests and Opinions

\begin{tabular}{lll}
\hline Activity & Interest & Opinion \\
\hline Work & Family & Ownself \\
Hobby & House & Social issues \\
Social activities & Work & Politics \\
Vacation & Community & Business \\
Entertainment & Recreation & Economics \\
Club Membership & Fashion & Education \\
Community & Food & Goods \\
Shopping & Media & Future \\
Sports & Achievements & Culture \\
\hline
\end{tabular}

Source: Joseph T. Plummer (1974)

A similar theory is submitted by Kotler, i.e., style and pattern of a person's life is based on his activities, interests and opinions. Therefore, lifestyle reflects the whole person's interaction with his surroundings (Kotler, 2008).

The above theory shows that there are various forms of lifestyles among adolescents. This is due to the differences in activities, interests and opinions. According to Chaney many forms of lifestyle exist in today's age (Chaney, 1996). However, this research focuses only on three forms, i.e., consumptive, modern and hedonistic. According to Yuanita a consumptive lifestyle is one which is controlled by the desire to buy goods which are not necessities, it is extravagant and excessive in fulfilling individual wants (Yuanita,2003). A consumptive lifestyle is also known as a Shopping Centre lifestyle(Prawono 2005), i.e., adolescents like to spend their time in a facilities-centred place which includes games centre, cinema, shopping centre, restaurants and prayer room. Consumptive behaviour is one which loves to spend and purchase goods in excess of need. It arises from adolescent materialistic tendency and desire for luxurious life (Prawono, 2005).

Next, a modern lifestyle is one with attitudes, behaviour or conduct and actions which suit the demands of time and is also known as a digital lifestyle. It is closely related to the use of something new and sophisticated, such as gadgets and social media. It also includes free mixing between men and women and contradicts Islamic values which prevent free mixing between men and women who are not their mahram.

A hedonistic lifestyle is one which practices luxury and pleasures in life. It is frequently related to unlimited luxury which involve practices such as sexy attire, mere entertainment, dancing which excites lust and everything else which destroys adolescent morality such as going to night clubs, smoking, drinking alcohol, drug or substance abuse like ecstacy pills and illegitimate sexual relations. In other words, a hedonistic lifestyle contradicts Islamic teachings which preserve the honour and sanctity of the Muslim community (Chaney,1996, Sharon Scales Rostosky,2004).

These three lifestyles are generally similar but there are slight differences between them. A consumptive lifestyle focuses on consuming goods and love of spending. A modern lifestyle is reflected in a person fashionable dressing, use of gadgets and accessories, possession of own transport and manner of socializing. And a hedonistic lifestyle is a free lifestyle which includes behaviour which loves entertainment in night clubs, drinking alcohol, drug or substance abuse like ecstasy pills and illegitimate sexual relations.

Islamic perspectives on the study of lifestyle are based on the Islamic model as a way of life. It intends to make the teachings of Islam derived from the Quran and al-Sunnah as a guidance to Muslim life. All forms of lifestyle must be consistent with the teachings of Islam. An individual / Muslim who does something against the teachings of Islam, means they do not practice the true Islamic lifestyle. 


\section{Literature Review}

The issue of adolescent lifestyle is currently and frequently the main topic of general conversation. This is due to the growth of trendy or latest lifestyles which results from the socio-cultural globalization process through various media and is frequently misused by adolescents in adopting a lifestyle that is clearly contradictory to Islamic values (Olivia M. Kaparang, 2013). Adolescent age is a transition period to find self-identity. Thus, adolescents frequently follow their desires to look fabulous or 'cool'. They are motivated to own something which is not a necessity thereby becoming consumptive.(Sintiche Ariesny Parma,2007). However, current modern lifestyle regards consumption as normal. This phenomenon occurs because of the self factor or the surroundings of the adolescents which encourage them to practise a certain lifestyle (Sintiche Ariesny Parma, 2007, Zainudin Sharif et al., 2011).

Meanwhile, studies about the relationship between lifestyle values (materialism, religiosity, physical well-being and image) and achievement goal orientation of college students enrolled in vocational programmes in Thailand, found that, a positive association with religiosity and personal well-being on the adoption of mastery goals (Chantara, Ravinder Koul \& Sittichai Kaewkuekool, 2014).

The inner influence, i.e., the desire to try and know something leads teenagers to practise a lifestyle which loves nightclubbing, smoking, drinking alcohol, taking ecstasy pills and illegitimate sexual relations with the attendant risk of out-of-wedlock pregnancy and HIVIAIDS infection (Sarnon et al., 2012), Salamatussaadah Abd. Ghafur et al., 2009), (Noremy Md. Akhir, 2008), (Nasrudin Subhi et al. 2012), (Sharon Scales Rostosky, 2004). This matter concerns the phenomenon of hedonism and cultural shock which afflict adolescents. AziziYahaya et al. (2012) state that the opening of increasingly more entertainment centres contribute to the moral decline of adolescents, compounded by the fact that operators of entertainment centres, being profit-oriented, could not care less about social and ethical issues(AziziYahaya et al., 2012). Thus, practising Islamic teachings help to develop a proper adolescent lifestyle.Abdullah NasihUlwan (1990) states that religious education is the foremost factor in building a person's character, and through it, influence the person's lifestyle (Abdullah Nasih Ulwan,1990). Religious education is required in the adolescent self to protect him from his own propensity to do negative acts such as being distracted by the pleasures and unfettered freedom of life.

Adherence to Islamic teachings helps to deter an adolescent from being influenced by a wanton lifestyle. Michelle, Thomas and Sinyangwe find that proper religious beliefs become good moral precepts in the adolescent self which direct him to think intelligently before doing something immoral(Michelle, Thomas and Sinyangwe,1989). This view reflects the importance of religious education towards building an excellent character in adolescents. Thus, religious values need to be imbued from childhood to enable a positive moral development within the adolescent self (Sarina, 1995), (Sharon Scales Rostosky, 2004).

\section{Research Methodology}

This is a survey study which uses a quantitative method. Questionnaire is used as research instrument consisting of 15 items covering three forms of lifestyle, namely consumptive, modern and hedonistic. This questionnaire uses the Likert scale from scale $1=$ strongly disagree to $5=$ strongly agree. A pilot study was done on 30 sample persons to test the reliability of questionnaire items. The result of the pilot study shows the overall Cronbach Alpha value obtained is high, i.e. 0.86 . This indicates that the questionnaire items used have a strong correlation, thus the items can be retained as acceptable and reliable.

Questionnaires were distributed to $(\mathrm{N}=510)$ adolescents in Bandar Baru Permas Jaya, Johor Bahru, Malaysia. The researcher chose students of Permas Jaya National Secondary School (2) and Permas Jaya National Secondary School (3) as research sample by simple random sampling.

Data is analysed using descriptive statistical technique, a technique which describes the state of data in a research sample. Statistical technique is used to analyse research findings from the questionnaire and explained in a table in the form of frequency (f), percentage (\%) and mean.

\section{Research Findingsand Discussion}

Questionaire items cover three forms of lifestyle: items 1 to 5 relate to a consumptive lifestyle, items 6 to 10 relate to a modern lifestyle and items 11 to 15 relate to a hedonistic lifestyle. Research results find that adolescents in Bandar Baru Permas Jaya, Johor Bahru, Malaysia practise all three forms of lifestyle. However, on comparison, the modern lifestyle is generally most practised by adolescents in Malaysia.

Regarding consumptive lifestyle, findings indicate the highest mean is wearing branded clothing and buying 
branded goods (mean=2.69). This shows that respondents are inclined towards a consumptive lifestyle in terms of using branded goods and clothing. Branded goods are expensive, especially international brands. Basically, spending is a concept which shows an attitude of acquiring goods as necessities. However, a consumptive lifestyle exists in this sophisticated age because all goods are known and easily available. Mass media such as television advertisements and internet frequently show new products with artistes as product ambassador to attract customers. Moreover, the trend now is not just shopping in shopping centres, but adolescents shop through the internet without limits and beyond boundaries. Thus, advertisements displayed in mass media encourage a consumptive lifestyle among teenagers because adolescents are easily influenced by marketing persuasion and want the new and latest things (Wan Norina Wan Hamat et al., 2013, AziziYahaya et al., 2012: 40, Sugiarto, 1999).

In addition, adolescent impulse which always strives in various ways to take care of and enhance their self-image so as to always look attractive results in their being more consumptive by buying branded goods and clothing (Sintiche Ariesny Parma, 2007).

As regards a modern lifestyle, research results find that the highest mean is exciting to attending social functions such as birthdays, new year and Valentine day celebrations (mean=2.79). This indicates that respondents like to follow and join in social functions. This is one of the modern characteristics practised by adolescents today. Basically, a modern lifestyle is socially positive. However, adolescents today abuse the time of these celebrations by celebrating in the wrong way, such as by free mixing between males and females, partying until late night and drinking alcohol. This is contradictory to a Muslim lifestyle as recommended by Islam. This phenomenon is customary for modern times and adolescents who are involved considered this as a normal lifestyle. But celebrations of such occasions have an effect on adolescent behaviour and morality (Idi Subandy Ibrahim, 1997).

The lowest mean for the modern lifestyle is having a boyfriend/girlfriend and going on frequent dates with him/her (mean=2.15). Even though this statement has the lowest mean, its existence shows that there are adolescents in Bandar BaruPermas Jaya, Johor Bahru who go on frequent dates with their lover at this young age. This phenomenon is against Islamic teachings which forbid free relationship between males and females who are non-mahram (Nasrudin Subhi et al., 2012).

Further, research findings show the highest mean for the hedonistic lifestyle is the smoker (mean=1.61). In this age, smoking is considered as enhancing a person's image to look tough or genthly, aside from helping to cope with stress and boredom. This phenomenon occurs because of adolescent impulse to try something new without considering its consequences causing damage to their personality and character. Adolescents also take up smoking because of overindulgence in their instinct for freedom (Noraini Ahmad, 1993, Nancy, 1997).

Although items for hedonistic lifestyle such as illegitimate sexual relations, taking ecstasy pills, nightclubbing and drinking alcohol score a low percentage, research findings show these have been going on among adolescents who adopt a hedonistic or also known as nightclubbing lifestyle in Malaysia. A nightclubbing lifestyle is the start to other hedonistic characteristics such as smoking, drinking alcohol, taking ecstasy pills and illegitimatae sexual relations. Hence, this phenomenon is against Islamic teachings and social morality in Malaysia as it is the cause of moral decay in society resulting in out-of-wedlock pregnancy, baby dumping and HIVIAIDS infection (Kim S. Miller et al., 2009, John S. Santelli 2001, SalasiahHaninHamjah, 2012).

Thus, it can be concluded that adolescents in Bandar Baru Permas Jaya, Johor Bahru, Malaysia practise all three forms of lifestyle. On comparison, the modern lifestyle is generally practised by the majority of adolescents in Malaysia. Table 3 shows the mean score of the modern lifestyle is the highest (mean=12.410) in comparison to consumptive and hedonistic lifestyles.

Table 2: Frequency, Percentage and Mean of Adolescent Lifestyles

\begin{tabular}{|c|c|c|c|c|c|c|}
\hline \multirow[b]{2}{*}{ Item } & \multicolumn{5}{|c|}{ Frequency (f) \& Percentage (\%) } & \multirow[b]{2}{*}{ Mean } \\
\hline & $\begin{array}{c}1 \\
\text { SDA }\end{array}$ & $\begin{array}{c}2 \\
D A\end{array}$ & $\begin{array}{c}3 \\
\text { NS }\end{array}$ & $\begin{array}{l}4 \\
\mathrm{~A}\end{array}$ & $\begin{array}{c}5 \\
\text { SA }\end{array}$ & \\
\hline 1.I only wear branded clothes and use branded goods. & $\begin{array}{c}72 \\
14.1\end{array}$ & $\begin{array}{l}130 \\
25.5\end{array}$ & $\begin{array}{c}216 \\
42.4\end{array}$ & $\begin{array}{c}69 \\
13.5\end{array}$ & $\begin{array}{l}23 \\
4.5\end{array}$ & 2.69 \\
\hline 2. I will change or buy a new handphonewhenever there is a more sophisticated model available. & $\begin{array}{l}158 \\
31.0\end{array}$ & $\begin{array}{c}201 \\
39.4\end{array}$ & $\begin{array}{l}125 \\
24.5\end{array}$ & $\begin{array}{l}20 \\
3.9\end{array}$ & $\begin{array}{c}6 \\
1.2\end{array}$ & 2.05 \\
\hline 3.I frequently eat at fast food restaurants such as KFC, Macdonald, Merrybrown, Pizza Hut and etc. & $\begin{array}{c}95 \\
18.6\end{array}$ & $\begin{array}{l}187 \\
36.7\end{array}$ & $\begin{array}{l}145 \\
28.4\end{array}$ & $\begin{array}{c}65 \\
12.7\end{array}$ & $\begin{array}{l}18 \\
3.5\end{array}$ & 2.46 \\
\hline 4. I like to go shopping and spend time in activities found in shopping centres. & $\begin{array}{l}155 \\
30.4\end{array}$ & $\begin{array}{l}165 \\
32.4\end{array}$ & $\begin{array}{l}116 \\
22.7\end{array}$ & $\begin{array}{c}56 \\
11.0\end{array}$ & $\begin{array}{l}18 \\
3.5\end{array}$ & 2.25 \\
\hline 5. I always follow and imitate the latest fashion worn by my favourite artistes. & 159 & 155 & 120 & 52 & 24 & 2.27 \\
\hline
\end{tabular}




\begin{tabular}{|c|c|c|c|c|c|c|}
\hline \multirow{3}{*}{ 6. I like simple dressing, look rugged and think of covering up more as unimportant. } & 31.2 & 30.4 & 23.5 & 10.2 & 4.7 & \multirow{3}{*}{2.32} \\
\hline & 187 & 129 & 89 & 56 & 49 & \\
\hline & 36.7 & 25.3 & 17.5 & 11.0 & 9.6 & \\
\hline \multirow{2}{*}{ 7. I talk and interact with friends using terms such as "amacam bro", "lumesticayasamagua" and so on. } & 128 & 116 & 129 & 93 & 44 & \multirow{2}{*}{2.63} \\
\hline & 25.1 & 22.7 & 25.3 & 18.2 & 8.6 & \\
\hline \multirow{2}{*}{ 8. I have a girlfriend/boyfriend and we go out on dates frequently. } & 189 & 140 & 115 & 48 & 18 & \multirow{2}{*}{2.15} \\
\hline & 37.1 & 27.5 & 22.5 & 9.4 & 3.5 & \\
\hline \multirow{2}{*}{ 9. I have my own transport such as motorbike, car or bicycle. } & 161 & 129 & 67 & 96 & 57 & \multirow{2}{*}{2.53} \\
\hline & 31.6 & 25.3 & 13.1 & 18.8 & 11.2 & \\
\hline \multirow{2}{*}{ 10. I like going to social functions such as birthday parties, new year celebrations and so on. } & 104 & 106 & 142 & 108 & 50 & \multirow{2}{*}{2.79} \\
\hline & 20.4 & 20.8 & 27.8 & 21.2 & 9.8 & \\
\hline \multirow{2}{*}{ 11.I frequently go out night clubbing. } & 419 & 54 & 13 & 12 & 12 & \multirow{2}{*}{1.32} \\
\hline & 82.2 & 10.6 & 2.5 & 2.4 & 2.4 & \\
\hline \multirow{2}{*}{ 12. I am a smoker. } & 371 & 46 & 34 & 38 & 21 & \multirow{2}{*}{1.61} \\
\hline & 72.7 & 9.0 & 6.7 & 7.5 & 4.1 & \\
\hline \multirow{2}{*}{ 13.I have tried free or illegitimate sexual relations. } & 445 & 33 & 16 & 9 & 7 & \multirow{2}{*}{1.24} \\
\hline & 87.3 & 6.5 & 3.1 & 1.8 & 1.4 & \\
\hline \multirow{2}{*}{ 14.I have tried drinking alcohol. } & 453 & 28 & 11 & 9 & 9 & \multirow{2}{*}{1.22} \\
\hline & 88.8 & 5.5 & 2.2 & 1.8 & 1.8 & \\
\hline \multirow{2}{*}{ 15.I have tried taking hallucinogenic pills such as ecstacy, ketamin, syabu and so on. } & 456 & 33 & 10 & 4 & 7 & \multirow{2}{*}{1.18} \\
\hline & 89.4 & 6.5 & 2.0 & 0.8 & 1.4 & \\
\hline
\end{tabular}

N: 510; SDA: Strongly disagree; DA: Diasgree; NS: Not Sure; A: Agree; SA: Strongly agree

Source: Questionnaire 2014

Table 3: Mean Score of Adolescent Lifestyle

\begin{tabular}{lc}
\hline Lifestyle & Mean Score \\
\hline Consumptive & 11.714 \\
Modern & 12.410 \\
Hedonistic & 6.573 \\
\hline
\end{tabular}

Source: Questionnaire 2014

This study proves that, young Muslims live in modern way, but still practice their religion. Although there are some who lead consumptive and hedonistic lifestyle, but the majority of adolescents does not transgress the norms and values of religion. Muslims have their own guidelines or model in their lives. They make Islam as a guidance / direction in their lives. Hence, Muslims live their lives on the basis of faith, worship and Islamic morality. The study found that, the religious factor is very important in influencing the lifestyles of adolescents.

\section{Conclusion}

Lifestyle is a person's life pattern which is the result of his daily activities, interests and opinions and reflects the whole person's interaction with his surroundings based on religious values and morals.By this definition, there are found in Malaysia three forms of lifestyle practised by adolescents, namely consumptive, modern and hedonistic. Thus, research results find that adolescents of Bandar BaruPermas Jaya, Johor Bahru, Malaysia practise these three lifestyles.On comparison, the modern lifestyle is generally practised by the majority of adolescents in Malaysia.Islam basically does not reject a modern lifestyle, so long as it is within the limits of morality and Islamic teachings. Therefore, this matter needs to be given attention so that adolescent lifestyle does not destroy their personal values as Muslims and contradict social values in Malaysia.

The study of lifestyle is very important because it can have implications in terms of identifying the Muslim adolescent's lifestyle today and the factors that affect their lifestyle. The study also has implications in terms of the influence of religion in adolescent's lifestyle. With this, the party associated with adolescent counselling can plan activities that fit the lifestyle of today's adolescents.

\section{References}

Ulwan, Abdullah Nasih.(1990). Guidance to Children's Education in Islam.Selangor: Klang Book Store AziziYahaya et al.(2012). Deviant Adolescent Behaviour: cause and Treatment.Malaysia: UTM Press 
Azriani Ab. Rahman\&Mohd Ismail Ibrahim.(2011). Read, my Girl. Kuala Lumpur: DewanBahasadanPustaka

C. Michelle, R.M Thomas dan I.M Sinyangwe.(1989). Adolescent Conception of Morals. Haiti The United States \& Zambia. Youth \& Society. 21 (2)

Chantara,SKoul ,R \&Kaewkuekool,S.(2014).Relationship between lifestyle values and achievement goal orientation among vocational students in Thailand.Journal of Beliefs \& Values Studies in Religion \&Education.page 36-47.

David Chaney.(1996). Lifestyles. London: Routledge

Engel, J. F, Blackwel, R.D., \&Miniard, P.W.(1990). Consumer Behavior.Edisi 6 ${ }^{\text {th }}$. USA: Dryden Press

Fauziah Ibrahim, Norulhida Sarnon, Khadijah Alavi, Mohd Suhaimi Mohamad, Noremy Md Akhir \& Salina Nen.(2012). Strengthening Religious Knowledge in Adolescents with Problematic Behaviour: Towards Building Proper Adolescent Character.Journal of Social Sciences and Humanities. 7: 84-93.

Glen H. Elder.(1968). Adolescent Socialization and Personality Development. Chicago: Rand McNally \& Company

Henry Assael.(1992). Consumer Behavior and Marketing Action.Edisi 2nd. Boston: Kent Publishing Company

Ibrahim Abu Shah, JamilHamali, Zulkifley Mohamed, Badron Abdul Manaf\& Allan Chong.(1999). Current Lifestyle: Analysis of Adolescent Cases in Kuching City. Shah Alam: BiroteksInstitutTeknologi Mara

Idi Subandy Ibrahim.(1997). Ecstasy of Pop Culture Lifestyle in Indonesian Commodity Society. Bandung: PenerbitMizan

John C. Mowen.(1995). Consumer Behavior. New Jersey Prentice Hall

John S. Santelli, Leah Robin, Nancy D. Brener \& Richard Lowry.(2001). Timing of Alchohol and Other Drug Use and Sexual Risk Behavior Among Unmarried Adolescent and Young Adults. Family Planning Perspectives. 33(5) 200-205

Joseph T. Plummer.(1974). The Concept and Application of Life Style Segmentation. Journal of Marketing. 38:33-37

Kim S. Miller, Amy M. Fasula, Melisa N. Poulsen, J. Terry Parker, Shannon Zackery, Sarah C. Wykoff \& Leslie F. Clark.(2009). Sexual Health Disparities Among African American Youth and the Need for Early Prevention Approaches: Parenting and Youth Development Programs as Strategies for Pre-Risk Prevention. The Journal of Equity in Health. 2(1) 12-28

Max Weber in Anthony Giddens.(2001). Sociology.Edisi $4^{\text {th }}$. UK: Blackwell Publisher

Nancy A. Rigotty, Joseph R. DiFranza, YuChiao Chang, Thelma Tisdale, Becky Kemp \& Daniel E. Singer.(1997). The Effect of Enforcing Tobacco-Sales Laws on Adolescents Acces to Tobacco and Smoking Behavior. The New England Journal of Medicine. 337(15) 1044-1051

NasrudinSubhi, Radhiah Abu Bakar, Norazura Ahmad, SuzanaMohdHoesni, Fauziah Ibrahim, MohdSuhaimiMohamad.(2012). Adolescent Sexual Relations: Between Love and Lust.Journal of Social Sciences and Humanities. 7:15-25.

Noraini Ahmad.(1993). Parents as Nurturers of Adolescent Personality.Ummi.Januari 1993

NoranFauziahYaakub, Abdul Rahman Md. Aroff, Othman Mohamed\& Abdul Aziz Zakaria.(1993). Family Dynamics and Adolescent Development: Perceptions of Malaysia Religious School Student. Paperwork Seventh Biennial Conference Asian Reigional Assiocation for Home Economics.19-23 July, Concord Hotel. Kuala Lumpur

NoremyMdAkhir.(2008). Malay Adolescent Involvement in Night Clubs and its Impact on Social Well-being.Paperwork onSeminar Soft Skill and Social Well-Being18-19 Ogos. MahkotaHotel, Melaka jilid 2:279-290.

Olivia M. Kaparang.(2013). Analysis of Adolescent Lifestyle in Imitation of Korean Pop through Television.Journal ActaDiurna. 2(2)

Philip Kotler\& Gary Amstrong.(2008). Principles of Marketing.Edisi12 ${ }^{\text {th }}$ : Prentice Hall

Prawono, IngeYuliana.(2005). Differences in Consumptive Behaviour for Fashion Products between Male and Female Adolescents. Jakarta: FakultasPsikologiUniversitasAtma Jaya Jakarta

RobiahKulopHamzah.(1993). Adolescence and Love.Kuala Lumpur: DewanBahasadanPustaka

SalamatussaadahAbd.Ghafur\& Nor Ba'yah Abdul Kadir.(2009). Romantic Relationships and Unwed Pregnant Adolescents In Rehabilitation Centres).Jurnal e-Bangi.Jilid 4 1:106-113.

Salasiah Hanin Hamjah, M. al-Adib Samuri, Rosmawati Mohamad Rasit, Fariza Md Sham, Zuliza Mohd Kusrin, Zainab Ismail, Nazirah Kamal Basah.(2012). Factors Relating to Premarital Pregnancy Among Muslim Adolescents in Malaysia.Journal of Medical Sciences. 6(6) 266-271

Sarina Othman.(1995). Managing Bosia Problem.Moral and Education. (7) 48-50

Sarnon, N., Mohamad, M. S, Fauziah et al.(2012). Out-of-WedlockPregnancy: Understanding Adolescents as a Basis for Family Intervention.Journal of Social Sciences and Humanities. 7: 121-130.

SayyidQutb.(1967). Fi Zilal al-Quran. Beirut: Dar al-Fikr

Sharon Scales Rostosky, Brian L. Wilcox, Margaret Laurie Comer Wright \& Brandy A. Randall.(2004). The Impact of Religiosity on Adolescent Sexual Behavior: A Review of the Evidence. Journal of Adolescent Research. 19(6) 677-697

SinticheAriesny Parma.(2007). Relation between Self-concept and Consumptive Behaviour of Female Adolescents in Purchase of Cosmetics through Catalogue in SMA. Thesis Master in PsychologyUniversitasDiponegoro Semarang

Sugiarto, E.(1999). PsychologicalTreatment in the Service Industry. Jakarta: PT GramediaPustakaUtama

Wahbah al-Zuhayli.(1989). TafsirMunir. Beirut: Dar al-Fikr al-Mua'asir

Wan Norina Wan Hamat, ZaharahHussin, Ahmad Fakrudin Mohamed Yusoff \& Ahmad ArifinSapar.(2013). Mass Media Influence on Character Appearance of Muslim Students in Malaysian Polytechnic. The Online Journal of Islamic Education. 1(1):17-27

Yuanita, Lisa.(2003). Overview of Consumptive Behaviour Occurrence inPurchase of Cellular Phones. Jakarta: Fakultas Psikologi Universitas Atma Jaya

Zainuddin Sharif \&NorazmahMohamadRoslan.(2011). Factors which influence Adolescents involved in Social Problems at Tunas Bakti School, Sungai Lereh Melaka. Journal of Education Psychology \& Counseling. 1:115-140. 